DOI 10.18551/rjoas.2019-09.28

\title{
SMART TOURISM DESTINATION MANAGEMENT IN KARANGASEM REGENCY OF INDONESIA
}

\author{
Sucipta Gusti Ngurah Karya*, Utama Made Suyana, Dewi Heny Urmila, \\ Yuliarmi Ni Nyoman \\ Faculty of Economics and Business, University of Udayana, Bali, Indonesia \\ *E-mail: ngurahks@gmail.com
}

\begin{abstract}
The management of tourism destinations in Karangasem Regency has implemented smart tourism by utilizing information and communication technology to face competition in the tourism sector. This study aims to analyze the effect of human capital, social capital, entrepreneurship, implementation of information and communication technology on the performance of smart tourism destinations in Karangasem Regency, Bali. This research was conducted on 155 samples of tourism industry owners in five tourist destinations in Karangasem Regency. The data obtained were analyzed with structural model equations using the Partial Least Square (PLS) program package. This study found that human capital, social capital, entrepreneurship, implementation of information and communication technology had a positive and significant effect on the performance of smart tourism destinations in Karangasem Regency.
\end{abstract}

\section{KEY WORDS}

Management, human capital, social capital, entrepreneurship, information, communication technology, smart tourism destinations.

Bali is already famous in the world in the field of tourism, because of its rich culture and natural beauty, so that tourist visits to Bali every year increase continuously. In several parts of Bali has also developed Tourism Destinations supported by 6-A which include Attractions, Accessibilities, Amenities, Available Packages, Activities, and Ancillary services. In competitive era, to increase tourist arrivals and improve services, smart tourism is developed. The emphasis on the concept of Smart Tourism Destinations is a new initiative to encourage innovation in tourism through the launch and development of Information and Communication Technology (ICT) systems such that different and competitive services can be created, which will increase competitiveness and profitability (Segitur, 2015).

The theory of tourism marketing refers to the study of Buhalis (2000) in Marketing the Competitive Destination describing that the marketing of tourism destinations must be coordinated by regional development strategic plans. If it related to marketing, the tourism destinations must also be able to optimize the impact of tourism and maximize its benefits for the tourism area. To further optimize the marketing of tourism destinations need to be supported by factors in Information and Communication Technology (ICT), innovation, social capital, and human capital for the intelligence (Boes et al, 2016). It is said that human capital and social capital can influence entrepreneurship and ICT implementation. Entrepreneurship and ICT implementation influence in improving business performance. Human capital and social capital affect business performance. Likewise, human capital and social capital influence business performance mediated by entrepreneurship and ICT implementation (Boes et al, 2016; Buhalis, 2015; Chevers, 2015).

In Karangasem Regency, Bali, there are 15 Tourism Destinations in 2012 to 2017, tourist visits fluctuate with a downward trend. In the management of tourism districts in this region, the Smart Tourism Destinations have been implemented, namely by implementing Information and Communication Technology (ICT). The implementation of ICT in each Tourism Destinations varies considerably depending on several factors, such as human capital, social capital, and entrepreneurship. Human capital and social capital capacity that is sufficient to be a reference to foster high entrepreneurial motivation in Tourism Destinations 
(Walzer, 2009). Based on the description, a study was conducted on the effect of human capital and social capital on entrepreneurship, ICT implementation and the performance of Smart Tourism Destinations in Karangasem Regency.

\section{LITERATURE REVIEW}

Management is a soft skills or skills to achieve a certain result using the power or help of others (Siagian, 1997). Terry (2005) defines management as the use of human resources or other resources that can be realized in planning, organizing, directing and controlling activities to achieve a certain goal. Human resources in the management of Tourism Destinations are owned by individuals, which are manifested in the quality of entrepreneurship, the quality of human capital involved and the quality of social capital.

Humans have certain abilities, if it used fully will produce extraordinary performance. Reliable human resource components are needed both in the organization and used individually. Human capital is education, knowledge, intelligence, information, ideas, skills, expertise and individual health. Referring to Becker's definition, there is something interesting, because it adds an extra dimension in terms of 'individual health'. The health and well-being of individuals is an important factor in contemporary research relating to the contextual development of human capital in organizations. Human capital is a concept that explains people in organizations and businesses as important and competent assets that have a contribution to the development and growth of a company. Attitudes, skills or expertise, health and human capabilities have a contribution to the performance and productivity of the organization (Becker, 1993).

Human capital influences the creation and success of new businesses, with a higher level of knowledge can increase the likelihood of becoming a successful entrepreneur. High entrepreneurial aspirations are often a prerequisite for entrepreneurial growth. Entrepreneurship is influenced by optimal human capital investment. Companies that invest high human capital in fact have a sales growth rate that affects income (Romao \& Neuts, 2017).

The key role played by tourism education and training in the sector's competitive strategy is the idea accepted by the various agencies that make up the tourism industry. Therefore, the facts prove that human capital factors in tourism cannot be separated related to the quality of tourism products in the Tourism Destinations. Human capital management and improvement in service quality can contribute to the further development and perfection of the socio-cultural and business scope of tourism destination. It can be interpreted that human capital is one of the main pillars of intelligence in urban and tourist destinations, besides infrastructure and information (Kurdashvili \& Meskhia, 2016). Thus in general there are 3 indicators that can be used to measure human capital which includes (1) education, (2) training and (3) health (Becker, 1993; Keeley, 2007).

Social capital is the amount of resources, actual or virtual that develops in individuals or groups of individuals. It is because of the ability to have a network that can last a long time in more or less relationships which has been institutionalized based on knowledge and mutual recognition. A stable relationship creates honor and reputation among its members, so that it is most effective for building and maintaining trust (Bourdieu \& Wacquant, 1992).

Social capital is also associated with values such as tolerance, solidarity, or trust. Capital approach states that economic, natural, human, and social capital are important resources for the present and future of individuals (Siegler, 2014). It can be interpreted that rich social capital in geographical areas including the presence of different networks between individuals, organizations and communities; collaboration and collaboration between such networks support collective knowledge and competitiveness. The most comprehensive definition of social capital is multidimensional, and combines of different units of analysis. Three main features as indicators of social capital: trust, norms and social networks (Pretty \& Ward, 2001).

Entrepreneurship requires the actions and activities of individuals who work within the company or for themselves. Entrepreneurship is the ability to create something new and 
different through creative thinking and innovative action to create opportunities in facing life challenges (Arisena, 2017). Entrepreneurs have the characteristics of: (1) innovative, namely perceiving and creating new opportunities, (2) operates under uncertainty and introduces products to the market, decides the location, shape and use of resources and (3) manages its business and competes with other market share (Braunerhjelm, 2010). Referring to the theory of Walzer (2009) and research (Dalimunthe, 2002; Farsi et al, 2013), indicators that can be used to describe entrepreneurship include motivation, innovation, opportunities and risk taking.

Buhalis \& Jun (2011) suggested that Information and Communication Technology (ICT) is a whole range of electronic tools, which facilitates the operational and strategic management of the organization by enabling it to manage information, functions and processes and to communicate interactively with stakeholders to achieve their mission and goals. The application of ICT that is applied in the tourism industry is E-Tourism. E-Tourism represents a paradigm shift experienced in the tourism industry as a result of the adoption of ICTs and the Internet. The concept of E-Tourism covers all business functions (e-commerce, e-marketing, e-finance and e-accounting, e-HRM, e-procurement, e-R \& D, e-production) as well as e-strategy, e-planning and e-management for all sectors of the tourism industry, travel, transportation, recreation, hospitality, intermediaries and public sector organizations (Buhalis et al, 2011).

There are different reasons for using ICT. Hotels located in Destinations Advanced tourism may use technology to distinguish themselves from competition in the local market, while hotels in developed destinations might try to attract tourists who are looking for something different. Utilizing ICT via Twitter, Facebook and other forms of social media provides a method for even small organizations to connect with potential customers and with successful Customer Relationship Management (CRM), they may be able to create longlasting relationships for future commercial profits (Ruiz -Molina et al, 2013).

Referring to the empirical study, the implementation of ICT can be measured by its indicators relating to Human Resources (HR) that have an impact on ICT investment or expenditure, the quantity of HR or labor used in the company as well as the scope of ICT utilized by the company. These indicators include:

1) Expenditures in the ICT sector, namely operational costs incurred in utilizing ICT facilities within the company in supporting tourism business activities, for example obtained from ICT investments. More investment in ICT can improve the quality of shipping services, product or service management, employees and customers and can increase customer satisfaction. Providing a budget with a reasonable percentage for ICT has an impact on better and faster customer service (Sadr, 2013).

2) Percentage of employees in the ICT field, which is the percentage of the number of skilled workers in the ICT field. If policymakers tend to pay attention to technological changes rather than changes in efficiency, policymakers place more emphasis on increasing technology investment rather than expanding employee quantity. Information technology has an effective role in the development of professional skills (Samoilenko \& Ngwenyama, 2011).

3) The scope in the field of ICT, namely hardware and software facilities that are used in the activities and marketing of Tourism Destinations which include (1) destination information server which is a destination database structure with internet interface, (2) room or package booking server equipped electronic payment systems, (3) data maintenance servers including property management systems and extranet and (4) internet utilization for accommodation and destinations (IFITT, 2014).

Smart Tourism is a development of E-Tourism can be seen as a logical development of traditional tourism. Smart Tourism has an understanding that intelligence is fostered by open innovation, supported by investment in human and social capital, and supported by participatory governance, to develop the collective competitiveness of tourism destinations to improve social, economic and environmental welfare for all stakeholders and provide value to visitors (Buhalis, 2015).

Smart Tourism Destinations are a component of Smart Tourism related to Tourism Destinations that have utilized Information and Communication Technology (ICT) in tourism 
services. Smart Tourism Destinations are Tourism Destinations that have digital 6A components (digital attractions, digital accessibility, digital facilities, digital tour packages, digital tourism activities and digital support services). Smart refers to all aspects of ICT connected to internet access (digital devices) and its infrastructure (Boes et al, 2016; Buhalis, 2015). The components of the Tourism Destinations and Smart Tourism Destinations are shown in Table 1.

Table 1 - Conventional Tourism Destination and Smart Tourism Destinations Analysis Framework

\begin{tabular}{ll|l}
\hline No. & Conventional Tourism Destinations Components & Smart Tourism Destinations Components \\
\hline 1 & Conventional attractions & Digital attractions \\
2 & Conventional accessibilities & Digital accessibilities \\
3 & Conventional amenities & Digital amenities \\
4 & Conventional tourism packages & Digital tourism packages \\
5 & Conventional tourism activities & Digital tourism activities \\
6 & Conventional ancillaries & Digital ancillaries \\
\hline
\end{tabular}

Sources: (Buhalis, 2000; Buhalis, 2015; Boes et al, 2016; Tran, 2017).

\section{METHODS OF RESEARCH}

The design used in this study is a quantitative design using an ordinal scale that is analyzed using a structural equation model (SEM) that is processed with partial least square (PLS) software. The framework, the conceptual framework of the research, and the research hypothesis, are based on the theories and research findings of previous researchers relevant to this study.

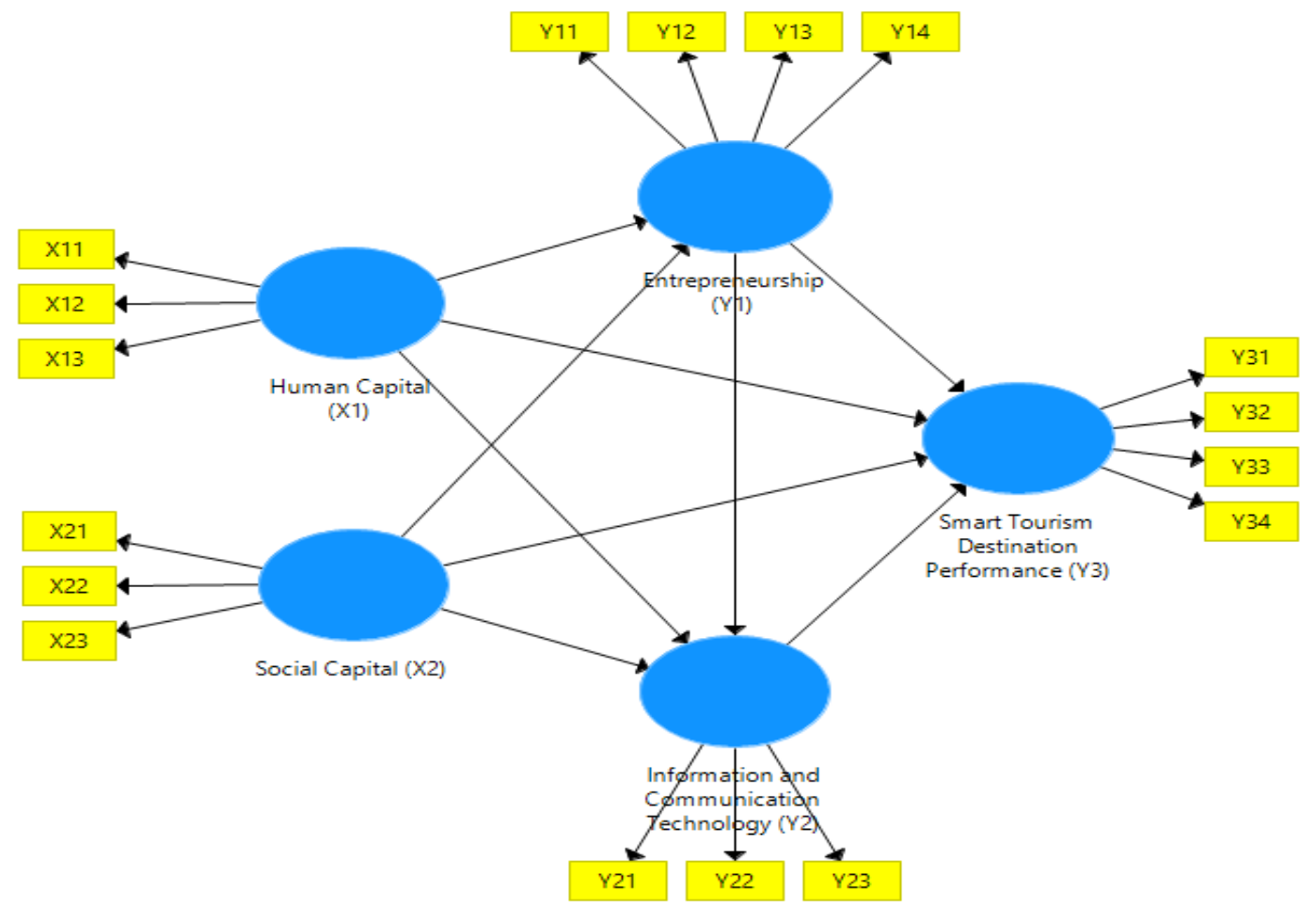

Figure 1 - Smart Tourism Destination Management Path Diagram in Karangasem Regency

Based on Figure 3.1, a research hypothesis can be made, namely:

1) Human capital and social capital have a positive effect on entrepreneurship in Karangsem Regency;

2) Human capital, social capital, and entrepreneurship have a positive effect on the implementation of Information and Communication Technology (ICT) in Karangsem Regency; 
3) Human capital, social capital, entrepreneurship, and ICT implementation have a positive effect on the performance of Smart Tourism Destinations in Karangsem Regency;

4) Human capital and social capital have an indirect effect on ICT implementation through entrepreneurship in Karangsem Regency;

5) Human capital, social capital, and entrepreneurship have an indirect effect on the performance of Smart Tourism Destinations through the implementation of ICT in Karangsem Regency.

This research was conducted in Karangasem Regency, Province of Bali, with the consideration that tourist destinations in this region have used ICTs in their management, but the number of tourist visits to each Tourism Destinations varied and fluctuated during 2013 2018.

This research uses primary and secondary data. Primary data are sourced from survey results obtained by first observing and then structured interviews using questionnaires or questionnaires to respondents in the study area, while secondary data are obtained from the Central Statistics Bureau, the Karangasem Regency Tourism Office and Province of Bali regarding the number of tourists visiting and management of Tourism Destinations.

The population of this research is the business in Tourism Destinations that apply information and communication technology in managing tourism businesses that include accommodation entrepreneurs, restaurant entrepreneurs and other tourism industry entrepreneurs in 5 Tourism Destinations in Karangasem Regency with total is 254 people. The population is accordance with the total number of companies studied, namely 254 business units or tourism industries in 5 Tourism Destinations classified as Karangasem Regency Smart Tourism Destinations. The samples used in this study are the owners of accommodation, restaurant and other tourism industries that use digital media on its business in 5 Tourism Destinations in Karangasem Regency which include (1) Tabola Village, (2) Padangbai, (3) Candidasa, (4) Amed and (5) Tulamben. The number of samples obtained for this study is 155 business owners determined by the Slovin method (Priyono, 2016).

Definition of Variable Operations:

1) Human Capital (X2) is a concept that explains people in organizations and businesses as important and competent assets that have a contribution to the development and growth of companies by indicators: i) education, ii) skills, and iii) health level, which is referred to Becker (1993).

2) Social Capital (X3) is a number of resources, actual or virtual that develop in an individual or group of individuals by indicators: i) trusting each other, ii) upholding common norms, and iii) establishing a network of cooperation to achieve certain goals, which referred to from Bourdieu \& Wacquant (1992).

3) Entrepreneurship (Y1) is a person's ability to create something new and different through: i) creative thinking, ii) acting innovative, iii) able to create opportunities, and iv) courage to face risks, referred to from: Swierczek \& Ha (2003).

4) Implementation of Information and Communication Technology or ICT (Y2) is the use of ICT by indicators: i) the amount of expenditure for ICT, ii) the percentage of skilled employees in ICT midwives, and iii) the reach of ICT access that is owned, referring to: Buhalis et al. (2011) \& IFITT (2014).

5) Smart Tourism Destination Performance (Y3) is a measure of the success of Tourism Destinations including business actors in them who run tourism businesses that are digitally technology integrated, by indicators: i) business development, ii) business income, and iii) employment, referenced from: Kaurav et al. (2015) \& Tran (2017).

The data obtained were analyzed by descriptive statistical methods and multivariate statistics. Multivariate statistics used in this study were Structural Equation Modeling (SEM) by Smart PLS (Partial Least Square) software. The relationship between research variables is shown in Figure 3.1.

The results of the processed data by PLS are then evaluated in two stages, firstly done through an outer model evaluation, and secondly an inner model. The first step is evaluating the measurement model or outer model which is carried out by the relationship between the 
indicator and its construct. The second stage of evaluation is done by looking at the validity of the inner model. In PLS the inner model is also called the inner relation which describes the relationship between latent variables based on the substance of the theory. There are three types of evaluations that are important to do on the inner model, such as (1) evaluation of goodness of fit, (2) test of direct influence, and (3) test of indirect effect or mediation. Before evaluating the inner model, a structural equation system is first made. Based on Figure 1, a structural equation system is made as follows.

The relationship between $\mathrm{X} 1$ and $\mathrm{X} 2$, towards $\mathrm{Y} 1$ :

$$
Y 1=\beta 1 X 1+\beta 2 X 2+\varepsilon 1
$$

The relationship between $\mathrm{X} 1, \mathrm{X} 2$, and $\mathrm{X} 3$, and $\mathrm{Y} 1$, to $\mathrm{Y} 2$ :

$$
Y=\beta 3 X 1+\beta 4 X 2+\beta 5 Y 1+\varepsilon 2
$$

The relationship between $\mathrm{X} 1, \mathrm{X} 2$, and $\mathrm{X} 3, \mathrm{Y} 1$, and $\mathrm{Y} 2$, to $\mathrm{Y} 3$ :

$$
Y=\beta 6 X 1+\beta 7 X 2+\beta 8 Y 1+\beta 9 Y 2+\varepsilon 3
$$

Where: X1: Human capital; X2: Social capital; Y1: Entrepreneurship; Y2: ICT Implementation; Y3: Smart Tourism Destination Performance; $\beta 1, \beta 2, \ldots$ and $\beta 12$ is the path coefficient; $\varepsilon 1, \varepsilon 2 \ldots$ and $\varepsilon 12$ is error.

\section{RESULTS AND DISCUSSION}

The results of PLS data processing of Smart Tourism Destination Management in Karangasem Regency are presented in Figure 2. It can be seen that the results of the research analysis show that there are 6 latent constructs with each supporting indicator, such as leadership variables, human capital, social capital, entrepreneurship, ICT implementation and Smart Tourism Destination performance having a loading factor value of 0.50 or more in accordance with Hair et al. (2014).

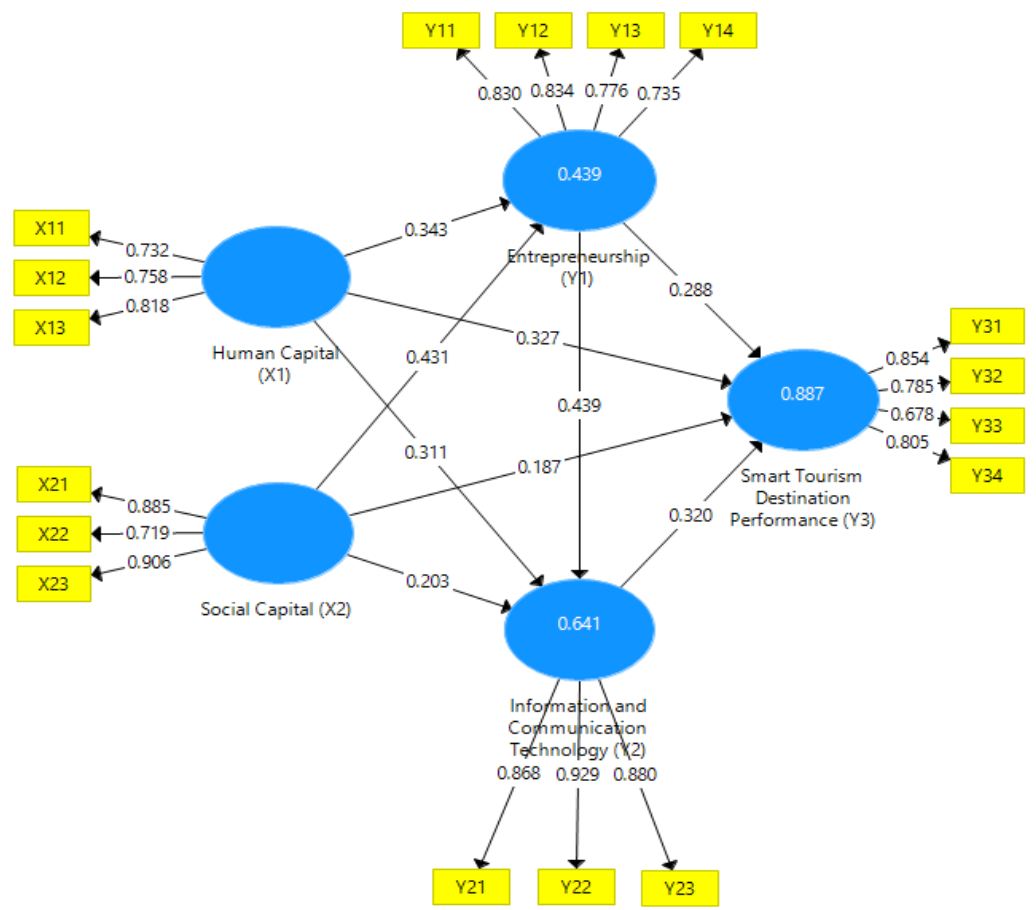

Figure 2 - Structural Equation Modeling of Smart Tourism Destination Management in Karangasem Regency 
The reliability and validity of the construct can be measured by the value of Average Variance Extracted (AVE), Composite Reliability, and Crombach's Alpha Construction of Smart Tourism Destination Management in Karangasem Regency as presented in Table 2.

Table 2 - Composite Reliability, Average Variance Extracted (AVE) and Alpha Cronbach Constructions of Intelligent Tourism Destination Management in Karangasem Regency

\begin{tabular}{lccc}
\hline \multicolumn{1}{c}{ Constructs } & Composite Reliability & $\begin{array}{c}\text { Average Variance } \\
\text { Extracted (AVE) }\end{array}$ & Alpha Cronbach \\
\hline Human capital & 0.814 & 0.594 & 0.665 \\
Social capital & 0.878 & 0.707 & 0.792 \\
Entrepreneurship & 0.873 & 0.632 & 0.805 \\
ICT Implementation & 0.921 & 0.797 & 0.872 \\
Smart Tourism Destination & 0.863 & 0.613 & 0.787 \\
Performance & & & \\
\hline
\end{tabular}

Based on the results of data processing shown in Table 2, it turns out that the Cronbach alpha value, Composite Reliability for each construct are all greater than 0.70 and in the Average Variance Extracted (AVE) greater than 0.50. It means the measurements used in this study are reliable.

Discriminant validity is intended to what extent a latent construct is able to discriminate itself with other latent constructs. Discriminant validity can be seen from the value of cross loading. If the cross loading value of a construct indicator is greater than other construct indicators, So, the construct has a discriminant validity. The results of the analysis show the cross loading value of each indicator to the construct is all greater than the other constructs. This shows that all indicators are valid for the construct.

Evaluation of structural model Goodness of Fit can be seen from the R-square coefficient value for each endogenous construct as shown in Table 3.

Table 3 - R-Square (R2) of constructs of Smart Tourism Destination Management in Karangasem Regency

\begin{tabular}{ccc}
\hline Constructs & $R$ Square & Description \\
\hline Entrepreneurship & 0.439 & Moderate \\
ICT Implementation & 0.641 & Moderate \\
Smart Tourism Destinations Performance & 0.887 & Strong \\
\hline
\end{tabular}

The $\mathrm{R}$ square for the entrepreneurship construct of 0.439 shows that variations in human capital and social capital can count for 43.9 percent of the variation in entrepreneurship. The relationship is classified as "moderate", because the value is less than 0.190 - 0.67. ICT implementation has an R squared of 0.641 indicating that variations in human capital, social capital, and entrepreneurship are able to explain 64.1 percent of the variations in ICT implementation. The relationship is "moderate", because it has a value of 0.64 below the value of 0.67 , while the $R$ square of the performance of Smart Tourism Destinations is 0.887 , meaning 88.7 percent, the influence of human capital, social capital, entrepreneurship, and ICT implementation is classified as "strong", because it has a value above 0.67 .

Based on $\mathrm{R}^{2}$ in Table 5.1 it can be calculated $\mathrm{Q}^{2}$ or stone Geiser by the formula:

$$
Q^{2}=1-\left\{\left(1-R^{2}{ }_{1}\right)\left(1-R^{2}{ }_{2}\right)\left(1-R^{2}{ }_{3}\right)\right\}=0,977
$$

Q2 value of 0.977 means that 97.7 percent of the variation of smart tourism performance in Karangasem Regency can be explained by variations in the constructs of Human Capital, Social Capital, Entrepreneurship and ICT Implementation, while the remaining 2.3 percent is explained by other variables outside the model.

To analyze the direct influence of a construct on other constructs as hypothesized, it can be seen the results of Path Coefficients calculations accompanied by T-statistics and Pvalues that can be presented in Table 4. 
Table 4 - The Direct Effect of the Context of Management of Smart Tourism Destinations in Karangasem Regency

\begin{tabular}{ccccc}
\hline Constructs Relationship & Original Sample & Standard Deviation & T Statistics & P Values \\
\hline X1-->Y1 & 0.343 & 0.086 & 4.016 & 0.000 \\
X2-->Y1 & 0.431 & 0.089 & 4.865 & 0.000 \\
X1-->Y2 & 0.311 & 0.074 & 4.181 & 0.000 \\
X2-->Y2 & 0.203 & 0.074 & 2.738 & 0.006 \\
Y1-->Y2 & 0.439 & 0.067 & 6.506 & 0.000 \\
X1-->Y3 & 0.327 & 0.050 & 6.514 & 0.000 \\
X2-->Y3 & 0.187 & 0.058 & 3.247 & 0.001 \\
Y1-->Y3 & 0.288 & 0.049 & 5.923 & 0.000 \\
Y2-->Y3 & 0.320 & 0.059 & 5.415 & 0.000 \\
\hline
\end{tabular}

Note: $X 1$ = Human capital; $X 2$ = Social capital; $Y 1=$ Entrepreneurship; Y2 = ICT Implementation; Y3 = Smart Tourism Destination performance.

Based on Table 4, it can be said that leadership, human capital, and social capital have a positive effect on entrepreneurship, i.e. with a $P$. Value of less than 0.01 . Leadership, human capital, social capital, and entrepreneurship have a positive effect on ICT implementation, also less than 0.05 , and also leadership, human capital, social capital, entrepreneurship, and ICT implementation have a positive effect on the performance of Smart Tourism Destinations in Karangasem Regency with $P$ Value is less than 0.01 .

Table 4 data also shows that the construct that has the greatest influence on entrepreneurship is social capital with a coefficient of 0.431 , while the lowest is human capital with a coefficient of 0.343 . The biggest influence on the implementation of ICT is entrepreneurship with a coefficient of 0.439 , while the lowest is social capital. On the other hand, the construct that most influences the performance of Smart Tourism Destinations is human capital with a coefficient of 0.327 , while the lowest is social capital with a coefficient of 0.187 .

Analysis of indirect effects can be used to explain the effect of an independent construct on the dependent construct through the construct between the results of the processed data with PLS the indirect effect or indirect effect is presented in Table 5.

Table 5 - The Indirect Effect of Constructs of Smart Tourism Destination Management in Karangasem Regency

\begin{tabular}{cccccc}
\hline $\begin{array}{c}\text { Relationship among } \\
\text { construct }\end{array}$ & $\begin{array}{c}\text { Mediation } \\
\text { Construct }\end{array}$ & $\begin{array}{c}\text { Original } \\
\text { Sample }\end{array}$ & $\begin{array}{c}\text { Standard } \\
\text { Deviation }\end{array}$ & T Statistics & P Values \\
\hline $\mathrm{X} 1 \rightarrow \mathrm{Y} 2$ & $\mathrm{Y} 1$ & 0.151 & 0.047 & 3.185 & 0.002 \\
$\mathrm{X} 2 \rightarrow \mathrm{Y} 2$ & $\mathrm{Y} 1$ & 0.189 & 0.053 & 3.586 & 0.000 \\
$\mathrm{X} 1 \rightarrow \mathrm{Y3}$ & $\mathrm{Y} 1, \mathrm{Y} 2$ & 0.247 & 0.052 & 4.759 & 0.000 \\
$\mathrm{X} 2 \rightarrow \mathrm{Y} 3$ & $\mathrm{Y} 1, \mathrm{Y} 2$ & 0.249 & 0.049 & 5.053 & 0.000 \\
$\mathrm{Y} 1 \rightarrow \mathrm{Y3}$ & $\mathrm{Y} 2$ & 0.140 & 0.034 & 4.140 & 0.000 \\
\hline
\end{tabular}

Source: Research Result, 2019. Note: $X 1=$ Human capital; $X 2$ = Social capital; $Y 1=$ Entrepreneurship; $Y 2=I C T$ Implementation; Y3 = Smart Tourism Destination performance.

Data of Table 5 shows that the construct of entrepreneurship mediates the effect of leadership, human capital, and social capital on entrepreneurship, ie with P. Value of less than 0.05 . The construct of ICT implementation plays a role in mediating the influence of leadership, human capital, and social capital, on the performance of Smart Tourism Destinations. Likewise entrepreneurship and ICT implementation together mediate the influence of the leadership construct, human capital, and social capital, on the performance of Smart Tourism Destinations in Karangasem Regency with P. Value of less than 0.05.

\section{DISCUSSION OF RESULTS}

Direct Effects of Human Capital, Social Capital on Entrepreneurship. Statistical results prove that human capital and social capital have a positive and significant influence on entrepreneurship. The findings of this study reflect that the existence of good quality human 
resources and social capital provides a great opportunity in enhancing the entrepreneurial spirit of tourism businesses in Karangasem Smart Tourism Destinations. This is in line with the study of human capital theory and empirical studies of human capital in relation to entrepreneurship. Factors forming human capital in research are in accordance with the study of Becker's theory (1993). Observations in the field show that each company always prioritizes the quality of its human resources in terms of their level of education, skills and health. Social capital with indicators of trust, norms, and networks, referred to Bourdieu \& Wacquant (1992) and Putnam (1993).

This research supports empirical studies that show that human capital influences the creation and success of new businesses, with a higher level of knowledge that can increase the likelihood of becoming a successful entrepreneur. High entrepreneurial aspirations are often a prerequisite for entrepreneurial growth (Madriz et al, 2018). This research study further supports research of Wahyudiono (2016) of the effect of education in the field of entrepreneurship on entrepreneurial attitudes. Education in the field of entrepreneurship if properly applied is able to encourage business, for example, the student entrepreneurship. This shows the importance of education as an indicator of human resources in determining entrepreneurial success.

There is a positive and significant influence of social capital on entrepreneurship. The findings of this study reflect that the existence of high social capital provides good social interaction between fellow entrepreneurs who can enhance the spirit of entrepreneurship in Karangasem Smart Tourism Destinations. This is in line with the study of social capital theory and empirical studies of social capital related to entrepreneurship. The study of theory shows a stable relationship creates honor and reputation among its members, so it is most effective for building and maintaining trust (Bourdieu \& Wacquant, 1992). Norms have a very important role that reflects how individuals must act in their environment. Collaboration between social networks supports collective knowledge and competitiveness (Pretty \& Ward, 2001).

Observations made in the field provide evidence of interrelations between stakeholders involved in the tourism business. The good relationship shown between the accommodation, restaurant and other tourism industry entrepreneurs is established continuously under any circumstances because it is based on a high sense of trust between fellow entrepreneurs. Cooperation between stakeholders and local entrepreneurs is a social network that plays a major role in the existence of tourism in the DTW concerned. This study is in line with empirical studies of social capital that have an effect on entrepreneurship. Research by Thobias et al. (2013), as social capital owned by the community such as trust, norms and social networks has a great influence on the development of entrepreneurial behavior, such as increasing public trust which is manifested in honest behavior and cooperation based on existing norms in society.

Direct Effects of Human Capital, Social Capital and Entrepreneurship on ICT Implementation. Hypothesis testing shows that human capital, social capital, and entrepreneurship have a positive and significant influence on the implementation of Information and Communication Technology (ICT). The findings of this study indicate that human capital, social capital, and high entrepreneurship have a positive impact on improving ICT implementation in Karangasem Smart Tourism Destinations. High human capital is very influential in determining optimal ICT expenditure, the number of skilled employees in the ICT field as well as facilitating management within the scope of ICT in the company.

This research supports the theory of human capital as well as the implementation of ICT in Tourism Destinations, which is related to the importance of human capital consisting of education, skills and health level of the workforce associated with success in the implementation of ICT in tourism companies proposed by Becker (1993), Keeley (2007) and Buhalis et al, 2011. High improvements in human capital can affect growth output in ICTrelated industries. This research study also supports the statement of Oluwatobietal. (2016) about human capital with its implementation of ICTs in small and medium enterprises (SMEs) as an effective marketing strategy in supporting business progress. 
The findings of this study indicate that high social capital has a positive impact on improving ICT implementation in Karangasem Smart Tourism Destinations. High social capital is very influential in the implementation of ICT, for example in the expenditure of ICT, skilled employees in the field of ICT as well as in the scope of ICT in the company. The foundation of social capital theory and empirical studies of social capital on ICT implementation can support this research. This relationship is reflected in the importance of social capital which includes trust, norms and social networks related to the implementation of ICT in tourism companies (Bourdieu \& Wacquant, 1992; Pretty \& Ward, 2001; Buhalis et al, 2011).

The results of this study are in line with empirical studies from Ahmed \& Alzahrani's (2017) \& Ahmed (2018) research which suggest the importance of social capital for the use of ICTs and investment strategies for building social capital can be adjusted to ensure successful ICT interventions. This research study also supports the statement of Fuhrer \& Cucchi (2010) which states that ICTs are used and show how they are conditioned by an individual's social capital in his professional network. Empirical study Yang et al. (2009) show patterns of interaction between ICTs and social capital can differ in developing and underdeveloped countries.

Direct Effects of Human Capital, Social Capital, Entrepreneurship, and the Implementation of Information and Communication Technology on Smart Tourism Destinations Performance. Hypothesis testing proves that human capital, social capital, entrepreneurship, and the implementation of information technology and communication have a positive and significant effect on the performance of Smart Tourism Destinations. The findings of this study reflect that the sufficient quantity of human capital has a positive impact on improving the business performance of companies in the Karangasem Smart Tourism Destinations, Province of Bali. Adequate quality of human resources is needed to improve company performance as seen from business development, and increased income, employment opportunities. This research study supports Helmiatin's (2015) empirical study about human capital that does not have an organization or company, but belongs to individual employees. So if the individual leaves the organization, there is no intelligence or creativity to use in the company. However, with various training programs employees can improve their personal abilities to support their performance and also improve company performance. This research is in accordance with the research study of Rismayadi (2015) which states that the level of education that is part of human capital affects employee productivity. Furthermore, increasing human capital by educating and attracting creative and knowledgeable people is at the core of intelligence success (Boes et al, 2016). Other empirical studies show a significant relationship of human capital to the performance of Tourist Destinations (Romao \& Neuts, 2017; Kurdashvili \& Meskhia, 2016)

The findings of this study reflect that well-established social capital has a positive impact on improving the business performance of companies in Karangasem Smart Tourism Destinations, Province of Bali. Company performance can improve not merely by relying on material capital and the use of labor or high human capital, but it is also necessary to pay attention to social capital among stakeholders. Low social capital can prevent companies in DTW from moving forward, for example promoting locally, nationally or internationally.

This research is in line with the study of social capital theory showing that good relationships created can build and maintain trust (Bourdieu \& Wacquant, 1992). Norms guide how individuals must act in their environment and social networks support competitiveness in companies (Pretty \& Ward, 2001). The role of social capital is seen at the local level in terms of trust, local norms, cooperation between local entrepreneurs who still maintain the concept of equalizing. Other aspects also play an important role, namely cooperation between entrepreneurs and suppliers, for example offline and online reservation agents. Cooperation with outsiders as suppliers / providers of tourism services can be easily carried out with high social capital, as a result of the existence of trust and good cooperation between business actors. The possibility to promote the company together can become easier. Along with the rapid development of ICT with the ease and security of online transactions, social capital directly influences company performance. 
This research study is in line with the empirical study of Athoillah (2017) that social capital is proven to have a positive and significant influence on performance, meaning that the higher the social capital, the more a sense of togetherness, solidarity, and at the same time will be responsible for joint progress, so that it will have an impact on high performance The explanation in the study also supports the empirical study Lee (2013) and Nasip et al. (2017) which describes the combination of knowledge (human capital) and cooperation (social capital) supporting collaborative online marketing activities in the Tourism Destinations. Social capital has a significant influence on economic, socio-cultural, environmental and business performance instruments at the destination.

This study shows that a high entrepreneurial spirit has a positive impact on improving ICT implementation in Karangasem Smart Tourism Destinations, Province of Bali. High entrepreneurial spirit is very influential in the implementation of ICT, for example in company policies on ICT expenditure, increasing the quantity of skilled employees in the field of ICT as well as managing the scope of ICT in the company properly.

The results of this study are in line with empirical studies from John et al. (2014) who put forward the importance of innovative entrepreneurship by utilizing ICT in Small and Medium Enterprises (SMEs), so that they can benefit more than those who do not utilize ICT. Park's (2017) empirical study suggests that business start-up and online entrepreneurship are being emphasized as strategies that individuals can change not only one's life but also the fate of an area and even the fate of a country.

Entrepreneurship has a positive and significant effect on the performance of Smart Tourism Destinations which is reflected in hypothesis testing. The findings of this study reflect that entrepreneurship is closely related to improving the company's business performance in Karangasem Smart Tourism Destinations. High entrepreneurship drives the seeds of new entrepreneurs in the tourism sector. This research supports the study of entrepreneurial theory which states that entrepreneurship is the ability to create something new and different through creative thinking and innovative action to create opportunities in facing life challenges that refer to Walzer's theory (2009) and Dalimunthe's (2002) research reveal indicators that can be used describing entrepreneurship including motivation, innovation, opportunities and risk taking.

The implementation of Information and Communication Technology (ICT) has a positive and significant effect on the performance of Smart Tourism Destinations which is reflected in hypothesis testing. The findings of this study indicate that the implementation of ICT has an influence in improving the business performance of companies in Karangasem Smart Tourism Destinations, Province of Bali. High ICT implementation can increase economic growth especially in the tourism sector. This study supports the study of ICT theory in Buhalis \& Jun (2011) which states that ICTs emerged as integrated network equipment and software systems, which enable effective data processing and communication for organizations to benefit towards organizational transformation into E-Business. Theory of Buhalis et al. (2011) revealed that since the 1980s, ICTs have changed tourism globally, creating applications and solutions often called E-Tourism. Indicators that can be used to describe ICT implementation include ICT expenditure, the percentage of ICT employees and the scope of ICT (Sadr, 2013; Samoilenko \& Ngwenyama, 2011; IFITT, 2014).

Entrepreneurship mediates the Effects of Human Capital and Social Capital on ICT Implementation. The results of research and data analysis show that human capital has an indirect effect on ICT implementation through entrepreneurship. Human capital directly has a positive and significant effect on entrepreneurship. Entrepreneurship directly has a positive and significant effect on ICT implementation. Human capital directly has a positive and significant effect on ICT implementation.

This mediating role of entrepreneurship supports the theories of entrepreneurship, leadership, human capital, social capital that were explained in the previous discussion. The mediation relationship is also supported by the theory of ICT implementation and Tourism Destinations (Buhalis \& Jun, 2011; Buhalis et al, 2011). Furthermore, this mediation relationship is based on a theory that can be used to describe the relationship between 
human capital, entrepreneurship and ICT implementation (Keeley, 2007; Walzer, 2009; IFITT, 2014).

The human capital of entrepreneurs in Karangasem Tourism Destinations indirectly influences the implementation of ICT through a high entrepreneurial spirit. Skilled human capital in the field of ICT is needed to enhance the entrepreneurial spirit that affects ICT implementation. Business Development will run well by increasing the use of ICT so that the company has high competitiveness with other companies in Karangasem Tourism Destinations. Human capital plays an important role in economic growth, especially in combination with the use of ICTs. John et al. (2014) suggested that strategies play a full role in ICT implementation in SMEs. Previous experience of entrepreneurial knowledge about ICT is significantly related to ICT performance. Park's (2017) empirical study revealed that entrepreneurship from the ICT field has contributed to the improvement of the creative economy by studying factors important for entrepreneurship and network development.

Testing the research hypothesis shows that social capital has an indirect effect on ICT implementation through entrepreneurship. This mediating relationship supports the theory of social capital which has indicators of trust, norms and social networks (Bourdieu \& Wacquant, 1992; Pretty \& Ward, 2001). Supporting theories of entrepreneurship (Arisena, 2017; Walzer, 2009) and mediation relationships are supported by the theory of ICT implementation and Tourism Destinations (Buhalis et al, 2011 \& IFITT, 2014). Further mediation relationships are based on these theories which can be used to describe the relationship of social capital, entrepreneurship and ICT implementation.

This study also supports the empirical study of Ahmed \& Alzahrani (2017) which explains that social capital influences ICT implementation, as long as the forms of ICT used are appropriate. The need to invest more in young ICT entrepreneurs in developing countries to increase their capacity to be competitive. The benefits of ICT implementation are seen in SMEs that have improved existing production procedures, increased productivity and reduced labor costs from the application of ICT.

Entrepreneurship mediates the Effects of Human Capital and Social Capital on Smart Tourism Destinations Performance. The research hypothesis shows that human capital has an indirect effect on the performance of Smart Tourism Destinations through entrepreneurship. Human capital used in a company shows its relationship with company performance through a high level of entrepreneurship. If entrepreneurship is classified as low, even though the company is equipped with quality human resources, the company is not capable of innovation, reads market opportunities and does not dare to take a risk, the company's performance will not increase. This research study supports the empirical study of Wajdi et al. (2018). It can be concluded that each aspect of entrepreneur's human capital has a significant effect on marketing performance. This study also supports the empirical study of Wahyudiono (2016) which explains that education as a component of human capital influences entrepreneurial attitudes. This reflects that education, especially related to entrepreneurship accompanied by maximum knowledge about entrepreneurship will be able to influence entrepreneurial motivation.

The results of the analysis of this study indicate that social capital has an indirect effect on the performance of Smart Tourism Destinations through entrepreneurship. The results of the analysis prove that social capital directly has a positive and significant effect on entrepreneurship. Collaboration in a business environment both between employees within a company and with entrepreneurs around the Tourism Destinations greatly influences business development going forward. Company performance is not only directly influenced by entrepreneurship, but is also related to social capital which helps to indirectly improve performance. According to observations that have been made in the field, for example in Padangbai Tourism Destinations, entrepreneurial interest needs to get the attention of all entrepreneurs in the Tourism Destinations. If there is good cooperation between fellow tourism entrepreneurs, for example there is no conflict in business interests, then the entrepreneurial spirit will increase and can improve the performance of businesses built in the area. 
Observations in Padangbai Tourism Destinations show good cooperation between employers in accommodation, restaurants and snorkeling services. When tourists come, both direct arrivals and delivered by a travel agent driver, the service to guests is very good. The snorkeling rental entrepreneurs in offering their services also do not forget to include lunch packages that will be aimed at restaurants around the Tourism Destinations. Furthermore, after they (tourists) enjoy the dish, offered a stay package by restaurant employees. A wellestablished relationship between one business actor and another can increase the income of fellow entrepreneurs even though they are in different business segments. The description described supports empirical studies that explain that social capital has a direct effect on entrepreneurship which has implications for performance. Good social capital will be able to increase entrepreneurship and have implications for company performance. This is in line with the empirical study of Carrion et al. (2016) which states that personal networks as part of social capital are positively related to small-scale economic performance moderated by the intensity of industrial competitiveness. Competitive industries that have a good entrepreneurial spirit affect the increase in company performance.

Testing the research hypothesis shows that human capital has an indirect effect on the performance of Smart Tourism Destinations through ICT implementation. Human capital directly has a positive and significant effect on the performance of Smart Tourism Destinations. The implementation of ICT directly has a positive and significant effect on the performance of Smart Tourism Destinations. Likewise, human capital directly has a positive and significant effect on ICT implementation.

This mediating relationship supports theories of human capital, social capital and entrepreneurship that affect the performance of Smart Tourism Destinations (CIPD, 2017 Keeley, 2007; Buhalis et al, 2011; Pretty \& Ward, 2001; Kaurav et al, 2015; Tran, 2017) The mediation relationship is based on this theory to describe the relationship between human capital, ICT implementation and the performance of Smart Tourism Destinations. Investing in human resources is more likely to adopt and use ICTs than others. This research study supports Helmiatin's (2015) empirical study of various employee training programs that can improve personal abilities to support their performance and also improve company performance.

Rismayadi research study (2015) which states that the level of education that is part of human capital affects employee productivity which will further influence in improving performance in the company. Increasing human capital by educating and attracting creative and knowledgeable people is at the core of intelligence success (Boes et al, 2016). Empirical studies also show a significant relationship of human capital to the performance of Tourism Destinations (Romao \& Neuts, 2017; Kurdashvili \& Meskhia, 2016).

The result shows that social capital has an indirect effect on the performance of Smart Tourism Destinations through the implementation of ICT. Mediation between these variables is based on theories that describe the relationship of social capital, ICT implementation and the performance of Smart Tourism Destinations. The social capital of entrepreneurs in Karangasem Tourism Destinations indirectly affects the performance of Smart Tourism Destinations through massive ICT implementation. Good social capital shown from good cooperation between fellow entrepreneurs as well as with online travel or reservation agents can improve ICT implementation which has an effect on improving business performance. This study is in line with the empirical study of Fuhrer \& Cucchi (2010) which sees from a managerial point of view that shows the influence of social relations in organizational management.

These relationships, as the dynamics of social capital, directly and indirectly affect the use of ICTs. This research study supports Lee's empirical study (2013) which revealed with the exception of trust and bonding strength, most components of social capital have a significant effect on the level of technology adoption Destination Management Organization. In Ahmed's research study (2018), social capital exists in a dynamic environment with personal, social, and organizational factors to influence the results of ICT interventions or in ICTs that influence the dimensions of social capital. An important conclusion emphasizes 
that structured social capital is the most powerful determinant of hotel performance, which can positively and significantly affect hotel occupancy.

Implementation of ICT mediates the Effects of Human Capital, Social Capital, and Entrepreneurship on Smart Tourism Destinations Performance. The research hypothesis testing shows that human capital and entrepreneurship have an indirect effect on the performance of Smart Tourism Destinations through the implementation of ICT. Human capital and entrepreneurship directly have a positive and significant effect on ICT implementation. The implementation of ICT directly has a positive and significant effect on the performance of Smart Tourism Destinations. Furthermore, human capital and entrepreneurship directly have a positive and significant effect on the performance of Smart Tourism Destinations.

Improving business performance with ICT implementation is highly dependent on human capital and a high entrepreneurial spirit while recognizing the importance of ICT that is implemented to the fullest. The relationship between ICT implementation that mediates human capital and entrepreneurship on the performance of Smart Tourism Destinations is implied in in-depth interviews related to ICT implementation that mediates human capital and Smart Tourism Destination performance and in-depth interviews that explain ICT implementation mediating the effect of entrepreneurship on the performance of Smart Tourism Destinations. This study is in line with the empirical study of Helmiatin (2015); Rismayadi (2015) and Boes et al. (2016). Romao \& Neuts (2017) which explains the effect of entrepreneurship on the performance of Smart Tourism Destinations. Furthermore this research supports the empirical study of Johnet al. (2014) and Park (2017) who explain the effect of entrepreneurship on ICT implementation. Likewise, the empirical study of Chevers (2015) and Ruiz-Molina et al. (2013) which shows the relationship between ICT implementation and the performance of Smart Tourism Destinations.

Social capital and entrepreneurship have an indirect effect on the performance of Smart Tourism Destinations through the implementation of ICTs reflected in the research hypothesis. Social capital and entrepreneurship directly have a positive and significant effect on ICT implementation. The implementation of ICT directly has a positive and significant effect on the performance of Smart Tourism Destinations. Likewise, social capital and entrepreneurship directly have a positive and significant effect on the performance of Smart Tourism Destinations.

The mediating relationship between these variables describes the relationship of social capital, entrepreneurship, ICT implementation and the performance of Smart Tourism Destinations. Improving business performance with ICT implementation is highly dependent on social capital and a high entrepreneurial spirit and realizing the importance of ICT in the current digital era facing the industrial revolution 4.0. The relationship of ICT implementation that mediates social capital and entrepreneurship to the performance of Smart Tourism Destinations is explained in in-depth interviews related to ICT implementation that mediates social capital and Smart Tourism Destination performance. This study is in line with the empirical study of Athoillah (2017 which states the relationship of social capital with the performance of Smart Tourism Destinations. The empirical study of Farsi et al. (2013) which explains the effect of entrepreneurship on the performance of Smart Tourism Destinations. This study supports the empirical study of Johnet al. (2014) which explains the effect of entrepreneurship on ICT implementation, Likewise the Chevers (2015) empirical study which shows the relationship of implementation ICT with Smart Tourism Destination performance.

The result shows that entrepreneurship has an indirect effect on the performance of Smart Tourism Destinations through the implementation of ICT. Entrepreneurship directly has a positive and significant effect on ICT implementation. The implementation of ICT directly has a positive and significant effect on the performance of Smart Tourism Destinations. Furthermore, entrepreneurship directly has a positive and significant effect on the performance of Smart Tourism Destinations.

This study is in line with the empirical study of John et al. (2014) which places innovation as a means to implement new ideas, create dynamic products and improve existing services. Therefore, team-based entrepreneurial activities are a strong determinant 
of ICT entrepreneurship development. The Chevers study (2015) explains the application of ICT in the hotel industry has resulted in lower costs, greater productivity, increased revenue, improved service quality and increased guest satisfaction. Hotel managers believe ICT adoption is a key success factor in improving hotel performance. Increasing operational productivity and customer satisfaction is seen as a major problem for long-term survival and success.

This study has two main findings from the discussion outlined earlier. The first finding shows that with an average labor force, most of whom are not tertiary graduates, employers are still able to develop their businesses, such as in Karangasem Regency, especially those working in 5 Karangasem Tourism Destinations (Tabola, Padangbai, Candidasa, Amed and Tulamben) areas. The number of non-college graduates who tend to be unskilled in the field of ICT can be overcome by providing Digital Marketing training to the workforce to improve their quality. This is an advantage of companies that continue to advance in the 5 Tourism Destinations studied in Karangasem Regency amid the limitations of qualified HR graduates from tertiary education.

The workforce owned by the company has the quality of human resources who are easily trained to understand and implement ICTs, so that they can support innovations made by the company on a regular basis. Digital businesses are also growing with increasing digital income, opening up digital jobs and exchanging communication and digital culture easily. The second finding shows that cooperation with external parties as suppliers / providers of tourism services, for example online reservation services is a form of "digital social capital" that can encourage high entrepreneurial spirit and optimal ICT implementation, so as to improve company performance in Smart Tourism Destinations.

This research has limitations that need to be studied again for subsequent researchers. Limitations contained in this study are:

a. This study uses variables with a limited number of indicators. These variables include human capital and social capital, each of which consists of three indicators. Human capital and social capital are reviewed using indicators commonly used in research. It is very possible that there are other indicators that make up the variables of human capital and social capital that can be reviewed. Likewise, several indicators other than those listed in the study can also support the variables of entrepreneurship, ICT implementation and the performance of Smart Tourism Destinations.

b. Research in the field is carried out using relatively short time, so the research time can be extended to get better results. These limitations affect the overall prediction of research in line with the development of tourism which changes from time to time in the 5 Tourism Destinations. It can be implied that if the model contained in the research is implemented in different situations, so it tends to lead to different results.

\section{CONCLUSION AND SUGGESTIONS}

Based on the results and discussion, it can be concluded that human capital and social capital have a positive and significant effect on entrepreneurship. Social capital has a dominant influence on increasing the entrepreneurial spirit. Human capital, social capital, and entrepreneurship have a positive and significant effect on the implementation of information and communication technology (ICT). Entrepreneurship is more dominant on influencing the implementation of ICT. Human capital, social capital, entrepreneurship, and ICT implementation have a positive and significant effect on the performance of Smart Tourism Destinations in Karangsem Regency. Human capital has a dominant effect on the performance of Smart Tourism Destinations. Entrepreneurship mediates the influence of human capital and social capital on ICT implementation in Karangasem Regency. ICT implementation mediates the effect of human capital, social capital and entrepreneurship on the performance of Smart Tourism Destinations in Karangsem Regency.

Referring to the results of the research and discussion described, suggestions that can be considered are more qualified Human Resources (HR) that need to be improved so that the entrepreneurial spirit of entrepreneurs increases. Human capital and social capital need 
to be further strengthened to optimize ICT implementation. Strong social capital, a high entrepreneurial spirit and optimal ICT implementation should be further improved in realizing better performance of Smart Tourism Destinations.

\section{REFERENCES}

1. Ahmed, Z. \& Alzahrani, A. 2017. Social Capital and ICT Intervention: A Search for Contextual Relation. Research Papers-ECIS 2017 Proceedings. 2000-2016.

2. Ahmed, Z. 2018. Explaining the Unpredictability: A Social Capital Perspective on ICT Intervention. International Journal of Information Management, 38, 175-186.

3. Arisena, G.M.K. 2017. Kewirausahaan. Diktat-Fakultas Pertanian. Denpasar: Universitas Udayana.

4. Athoillah. 2017. Model Peningkatan Knowledge Sharing Berbasis Modal Sosial and Learning OrganizationTerhadap Kinerja AgencyPada PT Prudential Life Assurance. EKOBIS, 18 (2), 174-183.

5. Becker, G. S. 1993. Human Capital: A Theoritical and Empirical Analysis, with Special Reference to Education. Third Edition. Chicago and London: University Of Chicago Press.

6. Boes, K, Buhalis, D. \& Inversini, A. 2015. Conceptualising Smart Tourism Destination Dimensions. Information and Communication Technologies in Tourism, 391-403.

7. Boes, K, Buhalis, D. \& Inversini, A. 2016. Smart Tourism Destinations: Ecosystems for Tourism Destination Competitiveness. International Journal of Tourism Cities, 2 (2), 108124.

8. Bourdieu, P. \& Wacquant, L.J.D. 1992. An Invitation to Reflexive Sociology. USA: Polity Press, Blackwell Publishers.

9. Braunerhjelm, P. 2010. Entrepreneurship, Innovation and Economic Growth: Past Experiences, Current Knowledge and Policy Implications. Research Network DebateSwedish Entrepreneurship Forum, Working Paper, 02:1-76.

10. Buhalis, D. \& Jun, S.H. 2011. E-Tourism. Contemporary Tourism Reviews. Goodfellow Publishers Limited.

11. Buhalis, D. 2000. Marketing the Competitive Destination of the Future. Tourism Management, 21:97-116.

12. Buhalis, D. 2015. Smart Tourism and the Competitive Destination of the Future. Bournemouth University. Available in: http://www.bournemouth.ac.uk.html. [downloaded: January, 19th 2018].

13. Buhalis, D, Leung, D. \& Law, R. 2011. eTourism: Critical Information and Communication Technologies for Tourism Destinations. In: Wang, Y. \& Pizam, A, editors. Destination Marketing and Management: Theories and Applications. United Kingdom: CABI Publishing.

14. Carrion, C.H, Izquierdo, C.C. \& Cillan, J.G. 2016. Entrepreneurs' Social Capital and Performance of Small Businesses: The Moderating Role of Competitive Intensity and Entrepreneurs Experience. Strategic Entrepreneurship Journal, 11 (1), 1-29.

15. Chevers, D.A. 2015. Evaluating the Impact of ICT Usage on the Performance of Jamaican Hotels: A Conceptual Perspective. Journal of Tourism and Hospitality Management, 3 (1-2), 22-31.

16. Dalimunthe, R.F. 2002. "Pengaruh Karakteristik Individu, Kewirausahaan, Gaya Kepemimpinan terhadap Kemampuan Usaha serta Keberhasilan Usaha Industri Kecil Tenun and Bordir di Sumatera Utara, Sumatera Barat and Riau" (disertasi). Surabaya: Universitas Airlangga.

17. Farsi, J.Y, Rezazadeh, A. \& Najmabadi, A.D. 2013. Social Capital and Organizational Innovation: The Mediating effect of Entrepreneurial Orientation.Journal of Community Positive Practices, 13 (2), 22-40.

18. Fuhrer, C. \& Cucchi, A. 2010. Relations Between Social Capital and Use of ICT; A Social Network Analysis Approach. NET 2010, 1-21. 
19. Hair, J.F, Black, W.C, Babin, B.J. \& Anderson, R.E. 2014. Multivariate Data Analysis. Seventh Editon (Revised). England: Pearson Education Limited.

20. Helmiatin. 2015. Optimalisasi Peran Modal Intelektual terhadap Kinerja Karyawan. Jurnal Etikonomi, 14 (1), 51-68.

21. International Federation for IT and Travel \& Tourism (IFITT). 2014. Information and Communication Technologies in Tourism.

22. John, A.G, Sunny, I. \& Horsfall, A. 2014. ICT Entrepreneurship and Small Business Innovation: A Mechanism for Sustainability. European Journal of Business and Social Sciences, 3 (6), 103-112.

23. Kaurav, R.P.S, Baber, R, Chowdhary, N. \& Kapadia, S. 2015. Destination Performance: Importance of Redefining DMOs. Asia-Pacific Journal of Innovation in Hospitality and Tourism, 4 (1), 125-142.

24. Keeley, B. 2007. Human Capital: How What You Know Shapes your Life. First Edition. Paris: OECD Publishing.

25. Kurdashvili, L. \& Meskhia, I. 2016. The Role of Human Capital in the Development of Tourism Business. Georgia: Ministry of the Regional Development and Infrastructure.

26. Lee, B.C. 2013. The Impact of Social Capital on Tourism Technology Adoption for Destination Marketing. Current Issues in Tourism, 18 (6),1-18.

27. Madriz, C, Leiva, J.C. \& Henn, R. 2018. Human and Social Capital as Drivers of Entrepreneurship. Small Business International Review, 2 (1), 29-42.

28. Nasip, S, Fabeil, N.F, Buncha, M.R, Hui, J.N.L. \& Sondoh, S.L. 2017. The Influence of Entrepreneurial and Social Capital on the Business Performance Among Woman Entrepreneurs Along West Coast Sabah, Malaysia. Proceedings of International Conference on Economics 2017, 377-395.

29. Oluwatobi, S.O, Olurinola, I.O. \& Taiwo, O. 2016. Human Capital Development in SubSaharan Africa: The Role of ICT.Journal of Economics Studies and Research, 2016, 111.

30. Park, C. 2017. A Study on Effect of Entrepreneurship on Entrepreneurial Intention: Focusing on ICT Majors. Asia Pacific Journal of Innovation and Entrepreneurship, 11 (2), 159-170.

31. Pretty, J. \& Ward, H. 2001. Social Capital and the Environment. World Development, 29 (2), 209-227.

32. Putnam, R.D. 1993. The Prosperous Community: Social Capital and Public Life. The American Prospect, 13:35-42.

33. Rismayadi, B. 2015. Faktor-faktor yang Mempengaruhi Produktivitas Karyawan (Studi Kasus pada CV Mitra Bersama Lestari Tahun 2014). Jurnal Manajemen and Bisnis, 1 (1), 1-16.

34. Romao, J. \& Neuts, B. 2017. Territorial Capital, Smart Tourism Specialization and Sustainable Regional Development: Experiences from Europe. Habitat International, 30:1-11.

35. Ruiz-Molina, M.E, Gil-Saura, I. \& Seric, M. 2013. The Use of ICT in Established and Emerging Tourist Destinations: a Comparative Analysis in Hotels. Journal of Hospitality and Tourism Technology, 4 (2), 96-118.

36. Sadr, S.M.H. 2013. The Role of ICT in Tourism Industry on Economic Growth: Case study Iran. European Journal of Business and Management, 5 (17), 159-165.

37. Samoilenko, S. \& Ngwenyama, O. 2011. Understanding the Human Capital Dimension of ICT and Economic Growth in Transition Economies. Journal of Global Information Technology Management, 14 (1), 59-79.

38. SEGITTUR. 2015. Smart Destinations Report: Building the Future. White Paper on Smart Cities, 1-206.

39. Siagian, S.P. 1997. Organisasi, Kepemimpinan and Perilaku Administrasi. Edisi 2. Jakarta: PT. Gunung Agung.

40. Siegler, V. 2014. Measuring Social Capital. Office for National Statistics. Available in: URL: http://www.ons.gov.uk/ons/dcp171766_371693.pdf. [downloaded: May, 23th 2018]. 
41. Swierczek, F.W. \& Ha, T.T. 2003. Motivation, Entrepreneurship and the Performance of SMEs in Vietnam. Journal of Enterprising Culture, 11 (1), 47-68.

42. Terry, G.R. 2005. Principles of Management. Alexander Hamilton Institute. New York.

43. Thobias, E, Tungka, A.K. \& Rogahang, J.J. 2013. Pengaruh Modal Sosial Terhadap Perilaku Kewirausahaan (Suatu studi pada pelaku usaha mikro kecil menengah di Kecamatan Kabaruan Kabupaten Kepulauan Talaud). Jurnal ACTA DIURNA, Edisi April 2013.

44. Tran, H.M, Huertas, A. \& Moreno, A. 2017. A New Framework for the Analysis of Smart Tourism Destinations. A Comparative Case Study of Two Spanish Destinations. Destinos Turisticos Inteligentes, 190-214.

45. Wahyudiono, A. 2016. Pengaruh Pendidikan Kewirausahaan, Pengalaman Berwirausaha, and Jenis Kelamin Terhadap Sikap Berwirausaha Pada Mahasiswa Fakultas Ekonomi Universitas Muhammadiyah Surabaya. Jurnal Ekonomi Pendidikan and Kewirausahaan, 4 (1), 76-91.

46. Wajdi, M.F, Mangifera, L, Wahyuddin, M. \& Isa, M. 2018. Peranan Aspek-aspek Modal Manusia Pengusaha terhadap Kinerja Bisnis UKM. Jurnal Ekonomi Manajemen Sumber Daya, 20 (2), 104-111.

47. Walzer, N. 2009. Entrepreneurship and Local Economic Development. First Paperback Edition. United Kingdom: Lexington Books. 